\title{
And religious conceptualizations of greed in the writing of Erich Fromm and John Chrysostom
}

\author{
Diana Martynova ${ }^{1}$, Elena Motovnikova ${ }^{1 *}$, Igor Boichuk ${ }^{1}$ \\ ${ }^{1}$ Belgorod State National Research University, 308015, Belgorod, Russia
}

\begin{abstract}
In modern society, which is conceptualized as a society of mass consumption and consumer culture, the discussion about the balance of the positively stimulating role and costs of the consumer attitudes as the basis of social behavior does not stop. The greatest danger of consumerism for a person lies, however, not in the socio-economic, but in the ethicalpsychological aspect of a person's life. This study seeks to clarify in which categories it is possible to achieve a productive understanding of the role of greed in the development of a person's spiritual world. A comparative analysis of the reasoning of the classics of Christian and atheistic humanistic ethics makes it possible to see the specifics of the anthropological consideration of greed and draw conclusions about the relevance of educational and pedagogical support to people who have taken the path to combat this spiritual ailment.
\end{abstract}

\section{Introduction}

The modern post-Christian secular society of market economy and consumerism culture inevitably puts a person in the contradictory position of an ever unsatisfied consumer, on the one hand, and an active participant in many communities and groups in which you need to show yourself open, generous, good companion and partner. It is impossible not to notice this contradiction between the philosophical and religious wisdom of the centuries, which speaks of greed as a mortal sin and moral deformity, and the pragmatic interest of modern civilization, in which greed is the engine of progress and the entire competitive global economy. In Russia, the acuteness of the problem is aggravated by the fact that a large part of the adult population brought up during the late Soviet period has not forgotten the ideals of communist morality, the secularized version of essentially Christian fraternity, selflessness and solidarity. The presence of a clearly defined point of reference makes the experience of competitive-individualistic relations accumulated over thirty years in various areas of Russian public and private life a convenient object of research into the effectiveness and costs of commercializing social institutions and creative activity. (cf., Kovalevskaya, 2009; Ishchenko, 2010; Farkhatdinov, 2011; Suvalko, 2013; Golovashina, 2016; Polyakov, 2016; Popova, 2016 et al.). Scientific psychology interprets the problem in terms of the dialectic of the measure and its violation: greed is seen as an exaggerated

\footnotetext{
${ }^{*}$ Corresponding author: motovnikova@bsu.edu.ru
} 
frugality and thrift, which not only does not bring happiness and satisfaction, but causes serious psychosomatic disorders; accordingly, scientific recommendations consist in keeping the passions under the control of the mind, training both thriftiness and generosity, helping the nearest and dearest as well as strangers (Shcherbatykh, 2010, pp. 132-166). However, in order to resort to the mental and spiritual resources of self-organization, you need to have a more or less clear idea of their present structure, that is, the anthropology of greed - at least until the "gene of greed" or its other psychophysiological carrier is detected. Such presuppositional, metascientific models are philosophical-religious conceptualizations that have not been refuted by science, the authors of which undertook a special rational study of a specific problem, in our case, the problem of the nature and specifics of the person who is covetous, a money-grubber and a miser. The tradition of researching this phenomenon as a political defect goes back to Plato, to his concept of "oligarchic man." To our understanding of individual predisposition (and personal responsibility) for developing or curbing a passion for possession is closer, however, to the teachings of Christian teacher John Chrysostom and humanistic psychoanalyst Erich Fromm, that have received worldwide recognition and in fact have become classics in this subject area.

\section{John Chrysostom: Greed as the Beginning of All Evil}

For a Christian, the most important work of life is to take care of the soul, of its posthumous existence, and that is why he is concerned about the question: how do you treat money, your personal possessions here on earth, in order to continue to rely on eternal life with God in the future. Possession of money and property, satiety and material well-being were never condemned by the saints or by Christ himself. "Not wealth is evil, but covetousness and avarice" (John, vol. II, p. 33). "Mention me not about the rich, but about those who cherish wealth. Job was rich, but did not serve mammon" (John, vol. VII, p. 243). A person falls into sin, becomes a hostage of money-love at the very moment when he begins to treat money not as a means, but as a goal. When the multiplication of material goods becomes not a household task, but the meaning of life, passion, captures the mind of a person, then other ideas and ideals do not achieve it. "No man can serve two masters: for either he will hate the one, and love the other; or else he will hold to the one and despise the other. You cannot serve God and mammon" (Matt. 6:24). This gospel truth expresses a subtle anthropological understanding of the hierarchy, the "unity of command" of the human heart: it is impossible to reach two summits at once, even if they are nearby. If the target summits are in contraposition, if one master orders to take and the other to give, then it is impossible to carry out their orders with the same zeal even theoretically; that is why "a rich man shall hardly enter into the kingdom of heaven" (Matt. 19:23). John Chrysostom saw around him that wealth most often leads a person to the sin of avarice. The multiplication of material benefits almost always begins to turn a man's head, he starts to want more; accumulation becomes the purpose of his life and work, of all his activity, worshiping thereby the "golden calf". "Do you not know that the more one has, the more he desires?" (John, vol. XII, p. 26); "Nothing arouses passion for riches like possessing it" (John, XI, p. 870). Turning his soul to wealth, worrying about its safety, a person turns away from the values of goodness and love: honesty and openness, trust and mercy. "It (the wealth) makes the soul vile $<\ldots>$ True, wealth makes (people) insane and mad" (John, Vol $\mathrm{XI}, \mathrm{pp} .415,417)$. "The soul of the rich is filled with all evils: pride, vanity, innumerable wishes, anger, rage, greed, lies and the like" (John, vol. IX, p. 132). So greed destroys the soul and the person, acquiring more and more, does not find peace, squanders and loses himself. 


\section{Erich fromm: greed as the loss of Freedom}

E. Fromm's ethical reasoning transforms into categorical and theoretical language eternal truths known to pre-scientific religious and philosophical psychology: "Consumption has inherent contradictory properties: on the one hand, it reduces the feeling of worry and anxiety, since what one possesses cannot be taken from him; but, on the other hand, it forces him to consume more and more, since all consumption soon ceases to be satisfying" (Fromm, 2010, p. 26). Belonging to the tradition of the Enlightenment, Fromm believed that religion is a historically transient form of searching for and finding the meaning of life as a balance and fullness of life. This search constitutes the philosophical and anthropological basis of being human in its constantly disharmonious "situation" in relations with nature, society, and himself. Society influences a person through his family, in which the child acquires the character necessary for a successful social life. In the formation of an individual character, the individual and cultural experiences of the individual, his temperament and constitution collide (see: Fromm, 2006a, p. 348-428). "A fully developed character, which is a goal of human development and at the same time an ideal of humanistic ethics" (ibid., p. 395) is a "fruitful character" whose owner freely and intelligently realizes his strengths and opportunities inherent in it.

Greed, avidity, as a system of orientation in life, is inherent in the "unproductive" type of character (ibid., p. 427). Since activity depends on an external source, and not on the person himself, he is active, but not fruitful. Acting not freely and not rationally, it is quite possible to come to material success (see: ibid., p. 399-400). This paradox Fromm explains with the help of the concept of "power", in which he sees two opposite meanings, "power ability and power - domination", the second being the perverted form of the first. When the power-abilities of the mind, love, imagination in relation to life are not developed or absent, "the human attitude to the world is distorted into a desire to dominate, to show one's power over others, to treat them as things" (ibid., p. 400-401). Dominance, therefore, stems from impotence, and not from the strength of the individual. "Fruitfulness is a setting that every human being is capable of, if not crippled mentally and emotionally" (ibid., p. 397). Freedom and self-development is a prerequisite for the deployment of all human abilities. "If freedom is taken away from him, he becomes sick, crippled, disabled" (Fromm, 2006b, p. 272).

\section{Conclusion}

In contrast to the physical needs that can be met, a greedy person will always be missing something for a complete "quenching thirst". Getting into the "web" of greed, we become aggressive, forced to strive for power, as a result of which between individuals there is competition and rivalry. As E. Fromm emphasizes, it is these individuals who are the creators of capitalism: in order to quench the thirst for enrichment, a person becomes a workaholic, devotes all his strength, attention and thoughts to work. We see that two ways of human existence in the world are the basis of ethical reflection on greed. The first is based on love, on the pursuit of good; second on the quest for submission to the world itself. Both ways are mutually exclusive. But if from a Christian point of view, greed definitely needs to be avoided in every way, then in modern consumer culture numerous "smoke curtains" have been created, called "to obscure all the main issues of personal and social life, all psychological, economic, political and moral problems" (Fromm, 2006a, p. 253). Under the pretext of an irresistible complexity, incomprehensibility to an ordinary person, people are discourage and deprived of desire to reflect, turning them into naive cynics. "The combination of cynicism and naivety is very typical for a modern individual, and the result of this combination is the fear of one's own thinking, one's own decisions" 
(ibid., p. 254).

Meanwhile, even if a consumer society, indeed, in development "is able to cope with its problems by itself, minimize the costs of an unlimited consumer culture" (Kurennoy, 2015) - after all, society should not and cannot solve the problem of freedom for every person and meaning of life, his self-consciousness, conscience and happiness.

\section{References}

1. E. Berdysheva, "You can't buy health": about the contradictions of the marketization of vital goods on the example of the market of dental services in Moscow, Laboratorium: Russian Review of Social Research, 2, 91-114 (2012)

2. N. G. Farkhatdinov, Art as a commodity: old and new research perspectives, Journal of Economic Sociology, 3(12), 127-144 (2011)

3. E. Fromm, Escape from Freedom. Man for Himself. An inquiry into the psychology of ethics (Moscow: AST, 2006)

4. E. Fromm, The Anatomy of Human Destructiveness, (Moscow: AST, 2006)

5. E. Fromm, To Have or to Be? (AST., Moscow, 2010)

6. O. V. Golovashina, Commercialization of the time: the value and price of the moment, Fractal Simulation, 1, 85-91 (2016)

7. S. A. Ishchenko, Commercialization in the international sports movement, The Reporter of Volzhsky University after V.N. Tatishchev, 72, 111-118 (2010).

8. St. John Chrysostom, Creations of our holy father John Chrysostom, Archbishop of Constantinople. [Tvoreniya svyatogo ottsa nashego Ioanna Zlatousta, Arkhiyepiskopa Konstantinopol'skogo]. St. Petersburg: Publication of the St. Petersburg Theological Academy v. I-XII. (1894-1911)

9. V. Kurennoy, Consumer Society PostNauka, information on: https://postnauka.ru/faq/41327

10. A. F. Polyakov, Commercialization of science: pro and contra, Simvol nauki, Omega science, 2, 242-245 (2016)

11. O. V. Popova, The Man, Its Price and Value: On the Problem of Body Commodification in Scientific Knowledge, Epistemology \& Philosophy of Science, 3(49), 140-157 (2016)

12. Y. Shcherbatykh, The seven deadly sins, or the psychology of vice for believers and unbelievers (Moscow: AST, 2010)

13. A. S. Suvalko, Emotional capitalism: the commercialization of the senses Preprint (Moscow: Publishing House of the Higher School of Economics, 2013). 